\title{
Zingerone in the Flower of Passiflora maliformis Attracts an Australian Fruit Fly, Bactrocera jarvisi (Tryon)
}

\author{
Soo Jean Park ${ }^{1, *}$, Stefano G. De Faveri ${ }^{2}$, Jodie Cheesman ${ }^{2}$, Benjamin L. Hanssen ${ }^{3}{ }^{(D}$, \\ Donald N. S. Cameron ${ }^{1}$, Ian M. Jamie ${ }^{3}$ (D) and Phillip W. Taylor ${ }^{1}$ \\ 1 Applied BioSciences, Faculty of Science and Engineering, Macquarie University, \\ Sydney, NSW 2109, Australia; donald.cameron@mq.edu.au (D.N.S.C.); phil.taylor@mq.edu.au (P.W.T.) \\ 2 Horticulture and Forestry Science, Queensland Department of Agriculture and Fisheries, \\ Mareeba, QLD 4880, Australia; stefano.defaveri@daf.qld.gov.au (S.G.D.F.); \\ jodie.cheesman@daf.qld.gov.au (J.C.) \\ 3 Department of Molecular Sciences, Faculty of Science and Engineering, Macquarie University, \\ Sydney, NSW 2109, Australia; benjamin.hanssen@hdr.mq.edu.au (B.L.H.); ian.jamie@mq.edu.au (I.M.J.) \\ * Correspondence: soojean.park@mq.edu.au; Tel.: +61-413-616-107
}

Academic Editors: Graham T. Eyres and Derek J. McPhee

Received: 5 May 2020; Accepted: 19 June 2020; Published: 22 June 2020

check for updates

\begin{abstract}
Passiflora maliformis is an introduced plant in Australia but its flowers are known to attract the native Jarvis's fruit fly, Bactrocera jarvisi (Tryon). The present study identifies and quantifies likely attractant(s) of male B. jarvisi in P. maliformis flowers. The chemical compositions of the inner and outer coronal filaments, anther, stigma, ovary, sepal, and petal of P. maliformis were separately extracted with ethanol and analyzed using gas chromatography-mass spectrometry (GC-MS). Polyisoprenoid lipid precursors, fatty acids and their derivatives, and phenylpropanoids were detected in P. maliformis flowers. Phenylpropanoids included raspberry ketone, cuelure, zingerone, and zingerol, although compositions varied markedly amongst the flower parts. P. maliformis flowers were open for less than one day, and the amounts of some of the compounds decreased throughout the day. The attraction of male $B$. jarvisi to $P$. maliformis flowers is most readily explained by the presence of zingerone in these flowers.
\end{abstract}

Keywords: passion fruit flower; Jarvis's fruit fly; phenylpropanoids; raspberry ketone; cuelure; GC-MS

\section{Introduction}

Mature males of many dacine fruit flies (Tephritidae) are attracted to the flowers of certain plants and this attraction is often related to the presence of either methyl eugenol (4-allyl-1,2-dimethoxybenzene) or raspberry ketone (4-(4-hydroxyphenyl)-2-butanone) in these flowers [1-6]. For example, the flowers of most Bulbophyllum orchids do not produce nectar, but instead produce volatile compounds to attract pollinators [7], including Bactrocera fruit flies [7-9]. A broad range of Bactrocera species is attracted to methyl eugenol and cuelure (4-(4-acetoxyphenyl)-2-butanone), a more volatile analog of raspberry ketone $[1,10,11]$. These are the standard lures used in surveillance and monitoring traps and for male annihilation techniques. Zingerone (4-(4-hydroxy-3-methoxyphenyl)-2-butanone) contains common functional groups from both methyl eugenol and cuelure, and the zingerone-containing flowers of Bulbophyllum patens attract a wide range of methyl eugenol and cuelure responsive flies [12]. Male flies that feed on methyl eugenol, raspberry ketone, or cuelure are known to gain substantial increases in sexual performance [13-17]. 
Bactrocera jarvisi (Tryon) is a moderate pest fruit fly in Northern Australia, having a host range of 83 species, of which 15 are cultivated [18]. The distribution of B. jarvisi is largely consistent with its native host, Planchonia careya (Cocky apple) [19], extending down the east coast of Australia, to as far south as Sydney, and across northern Australia into the Northern Territory and to Broome in Western Australia $[18,20]$. While they exhibit little response to cuelure, B. jarvisi males are strongly attracted to zingerone [21,22]. Bactrocera jarvisi males are attracted to the flowers of an Australian native orchid, $B u$. baileyi, which, like $B u$. patens, contains zingerone $[2,7,12]$. The attraction of $B$. jarvisi to flowers of the native tar tree, Semecarpus australiensis, and two exotic (American) passion fruits, Passiflora maliformis and P. ligularis, has been reported [22,23], but compound(s) responsible for this attraction have not been identified.

Passiflora maliformis is native to the Caribbean, Central America, and northern South America [24]. Although P. maliformis is not cultivated commercially, it does produce edible fruits [25-27]. The seeds of P. maliformis contain essential fatty acids [25], and the fruit juice has antioxidant activity [26]. Chemical profiles of whole fruit extracts of $P$. maliformis have been studied, reporting six major and 32 minor components [28]. Headspace profiles of P. maliformis flowers are known to contain indole as the major compound, bisabolene, geranyl acetone, 6-methyl-5-hepten-2-one, and (E)- $\beta$-ocimene [22]. However, the reported headspace profiles do not include phenylpropanoid compound(s) that are known to attract $B$. jarvisi [22].

The flowers of $P$. maliformis open for only one day before senescence, and the authors have observed that more $B$. jarvisi males are attracted to the coronal filaments of the flower in the morning than later in the day. Male Bactrocera is commonly more responsive to lures in the early morning than other times of the day [29-31], and so this observation may simply reflect diurnal patterns of $B$. jarvisi lure response. However, it may also be that $P$. maliformis flowers release more attractant(s) in the morning.

To ascertain the chemical basis for attraction of B. jarvisi to flowers of $P$. maliformis, a species with which they do not share an evolutionary history, the present study (1) identifies compound(s) in P. maliformis flowers that might attract male B. jarvisi, and (2) quantifies prospective attractant(s) in the flowers through the day.

\section{Results}

\subsection{Chemical Profiles of P. maliformis Flowers}

The identified compounds and their location in P. maliformis flowers are shown in Table 1. The flowers contained terpenoids, $\mathrm{C}_{16}$ and $\mathrm{C}_{18}$ fatty acids and their derivatives, phenylpropanoids, farnesol, farnesyl acetate, and squalene. Fatty acids and their derivatives and farnesol derivatives were most abundant in the coronal filament extracts. Fatty acids and their derivatives are most abundant in the reproductive organs, while terpenoids are most abundant in the petal and sepal. Phenylpropanoids included raspberry ketone, cuelure, zingerone, and zingerol. These are present but minor in the coronal filaments. Traces of raspberry ketone, cuelure, and zingerone were detected in the petal and sepal. The compounds, 3-ethyl-2,3-dihydro-4H-pyran-4-one and 1-(4-methyl-1,3-dioxolan-2-yl)pentan-3-one were tentatively identified (See Figure S1 and S2 in Supplementary Materials). 
Table 1. Chemical profiles of the seven assessed flower parts of $P$. maliformis. Relative abundances of chemicals were calculated by dividing the gas chromatography (GC) peak area of a compound by the sum of total peak areas of all compounds; The relative abundances were obtained from the 7 am samples; ${ }^{*}$ Tentatively identified compounds, further information is in the Supplementary Material; RI: Kovats retention index; Lit. RI: Literature retention index; ref: references for retention index with most similar GC conditions.; MM: molecular mass; ICF: inner coronal filament; OCF: outer coronal filament; SE: Standard error.

\begin{tabular}{|c|c|c|c|c|c|c|c|c|c|c|c|c|}
\hline No & Identity & RI & $\begin{array}{c}\text { Lit. RI } \\
\text { [ref] }\end{array}$ & MM & Diagnostic Ions & $\begin{array}{c}\text { ICF/\% } \\
\text { (SE) }\end{array}$ & $\begin{array}{c}\text { OCF/\% } \\
\text { (SE) }\end{array}$ & $\begin{array}{c}\text { Anther/\% } \\
\text { (SE) }\end{array}$ & $\begin{array}{l}\text { Stigma/\% } \% \\
\text { (SE) }\end{array}$ & $\begin{array}{c}\text { Ovary/\% } \\
\text { (SE) }\end{array}$ & $\begin{array}{l}\text { Petal/\% } \\
\text { (SE) }\end{array}$ & Sepal/\% (SE) \\
\hline 1 & $\beta$-Pinene & 980 & 978 [32] & 136.2 & $136,121,93,79,69,41$ & 0.0 & 0.0 & 0.0 & 0.0 & 0.0 & $\begin{array}{l}26.27 \\
(8.86)\end{array}$ & $25.39(9.21)$ \\
\hline 2 & 3-Ethyl-2,3-dihydro- $4 H$-pyran-4-one * & 1042 & & 126.1 & $126,98,81,70,53$ & $5.93(1.96)$ & $3.43(1.08)$ & 0.0 & $1.19(0.74)$ & $1.21(0.77)$ & $1.21(0.69)$ & $1.78(1.00)$ \\
\hline 3 & Borneol & 1175 & 1171 [33] & 154.2 & $154,139,123,110,95,55,41$ & 0.0 & 0.0 & 0.0 & $0.52(0.12)$ & $0.38(0.06)$ & $0.49(0.11)$ & $0.50(0.20)$ \\
\hline 4 & $\begin{array}{l}\text { 1-(4-Methyl-1,3-dioxolan- } \\
\text { 2-yl)pentan-3-one * }\end{array}$ & 1227 & & 172.2 & $172,143,128,99,85,82,72,57$ & $8.91(2.71)$ & $5.77(2.21)$ & $2.57(1.66)$ & $8.38(3.33)$ & $8.28(3.43)$ & $4.78(2.00)$ & $3.22(1.74)$ \\
\hline 6 & Nonanoic acid & 1278 & 1275 [34] & 158.2 & $129,115,73,60,57,41$ & $0.20(0.04)$ & $0.12(0.05)$ & $1.03(0.82)$ & $0.52(0.14)$ & $\begin{array}{c}0.53 \\
(0.14)\end{array}$ & $0.42(0.07)$ & $0.10(0.04)$ \\
\hline 7 & Indole & 1295 & 1294 [35] & 117.1 & 117,90 & $0.16(0.01)$ & $0.13(0.04)$ & $0.09(0.05)$ & 0.0 & $0.09(0.06)$ & $0.19(0.05)$ & $0.18(0.06)$ \\
\hline 8 & $\begin{array}{c}\text { 4-(2-Hydroxyisopropyl) } \\
\text {-1-methylcyclohexanol (Terpin) }\end{array}$ & 1315 & & 172.3 & $139,96,81,59,43$ & 0.0 & 0.0 & $2.02(1.04)$ & $1.22(0.63)$ & 0.0 & 0.0 & $1.04(0.71)$ \\
\hline 9 & $\begin{array}{l}\text { 4-(4-Hydroxyphenyl)- 2-butanone } \\
\text { (Raspberry ketone) }\end{array}$ & 1560 & 1556 [36] & 164.2 & 164,107 & $0.22(0.04)$ & $0.11(0.09)$ & 0.0 & 0.0 & 0.0 & $0.05(0.04)$ & $0.06(0.03)$ \\
\hline 10 & $\begin{array}{l}\text { 4-(4-Acetoxyphenyl)- 2-butanone } \\
\text { (Cuelure) }\end{array}$ & 1652 & & 206.2 & $206,164,107$ & $0.16(0.06)$ & $1.11(0.30)$ & 0.0 & 0.0 & 0.0 & $0.03(0.02)$ & $0.04(0.02)$ \\
\hline 11 & $\begin{array}{l}\text { 4-(4-Hydroxy-3-methoxyphenyl)- } \\
\text { 2-butanone (Zingerone) }\end{array}$ & 1663 & & 194.2 & 194,137 & $1.10(0.24)$ & $0.12(0.07)$ & 0.0 & 0.0 & 0.0 & $0.06(0.02)$ & $0.06(0.02)$ \\
\hline 12 & $\begin{array}{l}\text { 4-(4-Hydroxy-3-methoxyphenyl)- } \\
\text { 2-butanol (Zingerol) }\end{array}$ & 1688 & & 196.2 & 196,137 & $0.22(0.04)$ & 0.0 & 0.0 & 0.0 & 0.0 & 0.0 & 0.0 \\
\hline 13 & Propyl laurate & 1690 & 1685 [37] & 242.4 & $242,201,183,115,102,73,61,43$ & 0.0 & 0.0 & 0.0 & $1.88(1.00)$ & 0.0 & 0.0 & 0.0 \\
\hline 14 & $\begin{array}{c}\text { (2E,6E)-3,7,11-Trimethyldodeca- } \\
\text { 2,6,10-trien-1-ol (Farnesol) }\end{array}$ & 1732 & 1728 [38] & 222.4 & $222,136,121,107,93,81,69,41$ & $5.87(3.22)$ & $3.92(1.45)$ & 0.0 & 0.0 & 0.0 & 0.0 & 0.0 \\
\hline 15 & $\begin{array}{l}\text { 3,7,11-Trimethyl-2,6,10-dodecatrien- } \\
\text { 1-ol acetate (Farnesyl acetate) }\end{array}$ & 1849 & 1846 [39] & 264.4 & $\begin{array}{c}264,204,161,136,121,107,93,81, \\
69,43\end{array}$ & $7.78(2.34)$ & $8.31(2.45)$ & $0.42(0.18)$ & $1.76(1.10)$ & $1.02(0.47)$ & $0.58(0.20)$ & $0.52(0.22)$ \\
\hline 16 & Palmitic acid & 1978 & 1977 [40] & 256.4 & $256,312,185,171,157,129,73,57$ & $8.76(1.07)$ & $\begin{array}{l}17.82 \\
(5.78)\end{array}$ & $\begin{array}{l}12.27 \\
(4.84)\end{array}$ & $\begin{array}{l}12.52 \\
(5.02)\end{array}$ & $\begin{array}{l}13.47 \\
(5.62)\end{array}$ & $7.78(3.12)$ & $8.42(3.88)$ \\
\hline 17 & Ethyl palmitate & 1997 & $1996[41]$ & 284.5 & $284,241,157,101,88,70,55$ & $6.87(1.17)$ & $2.33(0.43)$ & $\begin{array}{l}19.08 \\
(6.66)\end{array}$ & $\begin{array}{r}14.89 \\
(5.98)\end{array}$ & $\begin{array}{l}15.08 \\
(6.13)\end{array}$ & $4.85(1.96)$ & $5.32(2.24)$ \\
\hline $\begin{array}{l}18 \\
19\end{array}$ & $\begin{array}{c}\text { Phytol } \\
\text { Linoleic acid }\end{array}$ & $\begin{array}{l}2121 \\
2157\end{array}$ & $\begin{array}{l}2117[41] \\
2156[42]\end{array}$ & $\begin{array}{l}296.5 \\
280.4\end{array}$ & $\begin{array}{c}123,111,97,81,71 \mathrm{~m}, 69,57 \\
280,150,138,124,109,95,81,67,55\end{array}$ & $\begin{array}{l}0.23(0.06) \\
2.38(0.62)\end{array}$ & $\begin{array}{l}0.24(0.09) \\
2.10(0.64)\end{array}$ & $\begin{array}{l}0.08(0.03) \\
8.28(3.35)\end{array}$ & $\begin{array}{l}3.86(2.02) \\
4.42(2.56)\end{array}$ & $\begin{array}{l}5.03(2.38) \\
5.86(2.18)\end{array}$ & $\begin{array}{l}1.82(0.98) \\
4.33(1.94)\end{array}$ & $\begin{array}{l}11.45(4.44) \\
5.78(2.21)\end{array}$ \\
\hline 20 & Linolenic acid & 2162 & $2162[34]$ & 278.4 & $\begin{array}{c}278,222,149,135,121,108,93,95 \\
79,67,55\end{array}$ & $1.83(0.76)$ & $4.32(1.76)$ & $2.22(1.08)$ & $5.11(2.88)$ & $4.63(2.23)$ & $2.82(1.21)$ & $3.61(1.22)$ \\
\hline 21 & Ethyl linoleate & 2171 & 2171 [43] & 308.5 & $308,262,109,95,81,67,55$ & $9.54(2.24)$ & $\begin{array}{l}15.23 \\
(4.63)\end{array}$ & $\begin{array}{l}18.41 \\
(6.33)\end{array}$ & $\begin{array}{l}19.45 \\
(7.21)\end{array}$ & $\begin{array}{l}17.94 \\
(6.12)\end{array}$ & $\begin{array}{l}16.36 \\
(5.05)\end{array}$ & $16.50(5.55)$ \\
\hline 22 & Ethyl linolenate & 2174 & $2173[44]$ & 306.5 & $\begin{array}{c}306,264,149,135,121,108,95,79, \\
67,55\end{array}$ & $2.03(1.34)$ & $2.21(1.46)$ & $\begin{array}{l}23.77 \\
(7.45)\end{array}$ & $9.52(3.32)$ & $9.44(3.33)$ & $3.70(1.83)$ & $3.82(2.00)$ \\
\hline 23 & Stearic acid & 2188 & 2188 [45] & 284.5 & $284,241,185,129,73,60,43$ & $1.84(0.78)$ & $2.10(1.05)$ & $1.12(0.32)$ & $3.83(1.23)$ & $6.52(2.28)$ & $1.84(0.92)$ & $1.79(1.04)$ \\
\hline 24 & Ethyl sterate & 2198 & 2197 [46] & 312.5 & $312,269,213,157,101,88,670,55$ & $2.13(0.83)$ & $1.43(0.93)$ & $4.03(2.72)$ & $6.02(3.44)$ & $4.77(1.75)$ & $0.72(0.32)$ & $1.02(0.41)$ \\
\hline 25 & Squalene & 2834 & 2833 [41] & 410.7 & $\begin{array}{c}367,341,203,175,161,136,121,85, \\
81,69\end{array}$ & $\begin{array}{c}33.83 \\
(10.01)\end{array}$ & $\begin{array}{c}32.58 \\
(10.21)\end{array}$ & $4.49(2.15)$ & $4.74(2.83)$ & $5.65(2.71)$ & $\begin{array}{l}19.85 \\
(7.02)\end{array}$ & $9.35(4.44)$ \\
\hline
\end{tabular}




\subsection{Diurnal Changes in Raspberry Ketone, Cuelure, Zingerone and Zingerol in P. maliformis Coronal Filaments}

Four known fruit fly attractants, raspberry ketone, cuelure, zingerone, and zingerol were detected. However, the compounds were not detected in all flower parts. The sepal and petal showed traces of raspberry ketone, cuelure, and zingerone, but as the amount was below the limit of detection of the generated standard curves, further quantification in these flower parts was not possible. Figure 1 illustrates changes in the amounts of the four compounds from 6 am to $5 \mathrm{pm}$ AEST. Statistical analysis showed that in the inner coronal filament, the amounts of raspberry ketone $\left(F_{11,46}=1.0, p>0.05\right)$, cuelure $\left(F_{11,46}=1.1, p>0.05\right)$, and zingerol $\left(F_{11,46}=1.6, p>0.05\right)$ did not change with flower collection time, but the amount of zingerone changed through the day $\left(F_{11,46}=6.4, p<0.0001\right)$. In the outer coronal filaments, the amount of cuelure $\left(F_{11,46}=2.7, p<0.01\right)$ and zingerone $\left(F_{11,46}=5.2, p<0.0001\right)$ changed through the day, but the amount of raspberry ketone $\left(F_{11,46}=1.1, p>0.05\right)$ and zingerol $\left(F_{11,46}\right.$ $=1.5, p>0.05$ ) did not change. Further analysis of non-linear least-squares fitting showed that the amounts of zingerone and cuelure decayed exponentially through the day (Table 2 and see residual plots in Figure S3 in Supplementary Materials). Although the data of the raspberry ketone in the inner coronal filament converged when fitted to the function, the fitting results showed that a decay pattern was not strong (Table 2 and Figure S3 in Supplementary Materials). The data of zingerol in both filaments, raspberry ketone in the outer coronal filament, and cuelure in the inner coronal filament did not converge to fit the function.
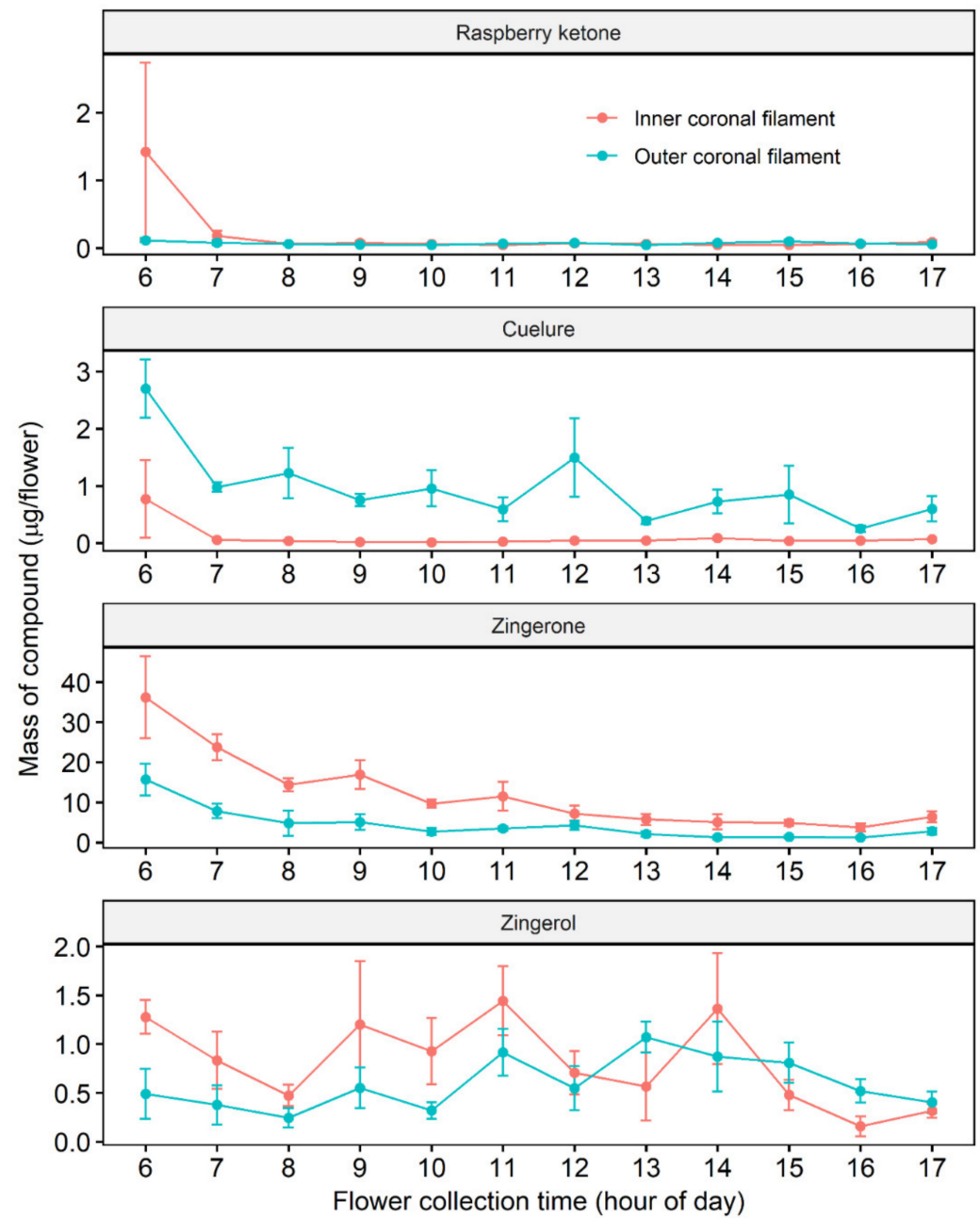

Figure 1. Diurnal changes of raspberry ketone, cuelure, zingerone, and zingerol in the coronal filaments of $P$. maliformis. Error bars represent standard errors that reflect variation across individual flowers. 
Table 2. Parameters from the curve fitting results for raspberry ketone, zingerone and cuelure. Fitted function: $f(y)=A \times e^{-k \times x}+\varepsilon ; \mathrm{A}=$ Initial value for $\mathrm{x}$ (collection time); SE: standard error; $\mathrm{k}=$ slope; $\varepsilon=$ correction factor; $\mathrm{T}_{1 / 2}=$ estimated half-life; $\mathrm{RSS}=$ residual sum-of-squares; $\mathrm{RSE}=$ residual standard error.

\begin{tabular}{ccccccc}
\hline Compound & Flower Part & $\mathbf{A}(\mathrm{SE})$ & $\mathcal{\varepsilon}(\mathrm{SE})$ & $\mathbf{k}(\mathrm{SE})$ & $\mathbf{T}_{\mathbf{1} / \mathbf{2}}$, Hour & RSS (RSE) \\
\hline $\begin{array}{c}\text { Raspberry } \\
\text { ketone }\end{array}$ & $\begin{array}{c}\text { Inner coronal } \\
\text { filament }\end{array}$ & $\begin{array}{c}3429000 \\
(6557000)\end{array}$ & $0.060(0.116)$ & $2.456(3.662)$ & 0.282 & $34.62(0.793)$ \\
Cuelure & $\begin{array}{c}\text { Outer coronal } \\
\text { filament } \\
\text { Inner coronal } \\
\text { filament }\end{array}$ & $\begin{array}{c}4200 \\
(245700)\end{array}$ & $0.768(0.112)$ & $1.667(1.789)$ & 0.964 & $31.51(0.756)$ \\
& $\begin{array}{c}365(259) \\
\text { Outer coronal } \\
\text { filament }\end{array}$ & $968(1166)$ & $2.247(0.575)$ & $0.719(1.307)$ & 1.682 & $563.4(3.200)$ \\
\hline
\end{tabular}

\section{Discussion}

The biosynthetic intermediates for polyisoprenoid lipids, such as farnesol, farnesyl acetate, and squalene, found in the flowers of P. maliformis are not unexpected as these are essential components involved in the mevalonate pathway in plants [47]. This pathway is also associated with the synthesis of terpenoids. Terpenoids, such as borneol, $\beta$-pinene, and terpin found in the current study, are structurally diverse and are the most common plant secondary metabolites [48]. Borneol and both $\alpha$ - and $\beta$-pinene are commonly found as volatile plant compounds [49-51]. Terpin is found in a bamboo species [52]. Release of volatile terpenoids, such as those reported in the present study, is implicated in the protection of plants against abiotic stresses, such as drought, high temperatures, and oxidative stresses [53,54], as well as biotic interactions, such as herbivores or pathogenic attacks [55]. The present study detected indole as a minor compound, while Fay reported it as the major compound along with several other compounds [22]. This inconsistency might have been due to the different sampling methods; the present study utilized solvent extraction of flower parts, while Fay entrapped headspace from cut vines with flowers. Given that biosynthesis and accumulation of volatiles are highly compartmentalized and restricted to specific tissues [56-58], and emission profiles can vary with flower conditions during the sampling $[59,60]$, the inconsistency is not unprecedented. The occurrence of saturated and unsaturated fatty acids and their derivatives, including a suite of $\mathrm{C}_{18}$ fatty acid derivatives, is ubiquitous in plants [61]. These acids are building blocks for very long-chain fatty acids that are precursors for the synthesis of sphingolipids, important molecules involved in signal transduction and regulation of cell death [62].

The detected phenylpropanoids, including raspberry ketone, cuelure, zingerone, and zingerol in the coronal filaments confirms the previous speculation that the flower of $P$. maliformis may contain zingerone that attracts $B$. jarvisi males $[21,22]$. Some volatile phenylpropanoids are emitted as floral attractants to pollinators or as defense compounds against microorganisms, insects, and mammalian predators [63-65]. Likewise, the phenylpropanoids found in this exotic plant are floral attractants to Bactrocera species in Australia, although their functions in the plant's native environment are not known.

The production and emission of volatile compounds in plants increase during the early stages of organ development and then either remain relatively constant or decrease over the organs' lifespan [64]. This trend was observed in the present study in that the amounts of zingerone in both coronal filaments and cuelure in the outer coronal filament decayed exponentially, and that of the other compounds remained unchanged or did not show a strong decay pattern. The release of floral volatiles is also controlled by circadian clock [66,67], and environmental factors, such as light, temperature, and humidity [68]. The overall amounts of zingerone detected in the corona were higher in the inner filaments than in the outer filaments (Figure 1). Cuelure was known only as a synthetic attractant [1] until recent studies reported the occurrence of cuelure in nature [69-71]. The present study also demonstrates cuelure as a naturally occurring compound. If the flowers released sufficient cuelure and 
raspberry ketone, then cuelure-responding species should be attracted. The amount of cuelure and raspberry ketone in the flowers was barely detectable, which likely explains why the flowers have not been reported to attract cuelure-responding species. The attraction of $B$. jarvisi to zingerone is as strong as that of $B$. dorsalis to methyl eugenol [21]. The efficacy of cuelure to cuelure-responding species is not as strong as that of methyl eugenol to methyl eugenol responding species [72,73]. In combination with the very low levels of cuelure and raspberry ketone in the flowers, the weaker efficacy of cuelure and raspberry ketone may also explain why species that are attracted to these compounds have not been reported on $P$. maliformis flowers.

The release of floral volatiles in plants often coincides with the foraging activities of potential pollinators and is usually regulated by light [64]. Although there is variation in insect pollination between Passiflora species [74], generally, the pollinators for Passiflora include bees, hummingbirds, and bats [75-77]. The corona of Passiflora is known to act as a visual and olfactory stimulus to its pollinators [78]. Substances in the corona of Passiflora, including phenylpropanoids, may play a role in attracting pollinators. The diurnal patterns of zingerone and cuelure contents of P. maliformis flowers coincide with the typical diurnal pattern of responsiveness of Bactrocera males, which are usually more responsive to phenylpropanoid attractants in the early morning [29-31]. Further study is needed to confirm whether peak responsiveness of $B$. jarvisi to phenylpropanoids corresponds with the timing of the greatest amounts of phenylpropanoids in P. maliformis. However, such correspondence cannot be explained in evolutionary terms, as the natural range of $P$. maliformis does not coincide with that of any known Bactrocera species. The functional significance of zingerone and other phenylpropanoids in P. maliformis flowers and its significance to pollinators in the natural range of this plant is currently unclear.

In summary, the present study finds a cause of interaction between an exotic plant, P. maliformis and an Australian native fruit fly, B. jarvisi to be most likely by plant-produced zingerone, a volatile compound that is highly attractive to $B$. jarvisi and is also released by flowers of some native plants to attract insect pollinators.

\section{Materials and Methods}

\subsection{Chemicals}

For positive identification of the compounds in $P$. maliformis flowers, $\beta$-pinene, borneol, indole, terpin, raspberry ketone (4-(4-hydroxyphenyl)-2-butanone), cuelure (4-(4-acetoxyphenyl)-2-butanone), zingerone (4-(4-hydroxy-3-methoxyphenyl)-2-butanone), farnesol, palmitic acid, ethyl palmitate, phytol, linolenic acid, ethyl linoleate, ethyl linolenate, stearic acid, ethyl stearate, and squalene were purchased from Sigma-Aldrich (Merck KGaA, Darmstadt, Germany). Nonanoic acid was purchased from Acros Organics (Thermo Fisher Scientific, Geel, Belgium). Propyl laurate was purchased from AbovChem (AbovChem LLC, San Diego, CA, USA). Farnesyl acetate (a mixture of isomers) was purchased from TCI (Tokyo Chemical Industry Co., Ltd. Tokyo, Japan). Linoleic acid was purchased from Alfa-Aesar (Thermo Fisher Scientific, Lancashire, UK). The chemicals were analytical or reagent grade with $98 \%$ or higher purity and used without further purifications. Zingerol (4-(4-hydroxy-3-methoxyphenyl)-2-butanol) was synthesized by the reduction of zingerone with sodium borohydride in methanol (See Supplementary Materials for synthetic details).

\subsection{Flower Extraction}

Flowers of P. maliformis (Voucher number: CNS 147961.1, Australian Tropical Herbarium) were collected between January 2017 and October 2018 at the Mareeba Research Facility of the Queensland Department of Agriculture and Fisheries (17.007007 $\left.\mathrm{S}, 145.429446^{\circ} \mathrm{E}\right)$. The flowers were collected hourly from 6 am to 5 pm AEST with at least three replicates at each hour. Following collection, the inner and outer coronal filaments, anther, stigma, ovary, sepal, and petal were separated (see Figure S4 in Supplementary Material for the organization of the flower organs), cut into fine pieces and stored in 
absolute ethanol $(1 \mathrm{~mL})$ in 2 or $4 \mathrm{~mL}$ glass vials at $4{ }^{\circ} \mathrm{C}$ until further extraction. Scissors and forceps were decontaminated with $100 \%$ ethanol in between dissecting and cutting the separated flower parts. The ethanol extracts were partitioned between aqueous and organic layers by adding water $(1 \mathrm{~mL})$ and ethyl acetate in hexane $(10 \%(v / v), 2 \mathrm{~mL})$. The organic layer was separated, and the aqueous layer was further extracted with ethyl acetate in hexane $(10 \%(v / v), 2 \mathrm{~mL} \times 2)$ using a separatory funnel. The organic layers were combined, washed with deionized water $(5 \mathrm{~mL})$, dried over anhydrous sodium sulfate, and concentrated under reduced pressure. Where necessary, the concentrate was diluted with dichloromethane to give a sample volume of $200 \mu \mathrm{L}$ that was subjected to gas chromatography-mass spectrometry (GC-MS) analysis.

\subsection{Gas Chromatography-Mass Spectrometry (GC-MS) Analysis}

GC-MS analysis was performed on a Shimadzu GCMS QP2010 or Shimadzu GCMS TQ8030 spectrometer equipped with a split/splitless injector, fused silica capillary column (SH-Rtx-5MS, $30 \mathrm{~m} \times 0.25 \mathrm{~mm}$ I.D. $\times 0.25 \mu \mathrm{m}$ film thickness) with crossbond 5\% diphenyl/95\% dimethyl polysiloxane as the stationary phase and integrated mass spectrometry (MS). Helium gas (BOC, North Ryde, NSW, Australia) (99.999\%) was used as a carrier gas with a constant flow of $1.0 \mathrm{~mL} / \mathrm{min}$. The injection was $1 \mu \mathrm{L}$ of a sample at $270{ }^{\circ} \mathrm{C}$. The initial column temperature was set at $60{ }^{\circ} \mathrm{C}$ and held for $4 \mathrm{~min}$, increased to $200{ }^{\circ} \mathrm{C}$ at a rate of $10^{\circ} \mathrm{C} / \mathrm{min}$, then increased to $300^{\circ} \mathrm{C}$ at a rate of $40{ }^{\circ} \mathrm{C} / \mathrm{min}$, and held for $7 \mathrm{~min}$. The temperatures of the interface and ion source box were set at 250 and $230{ }^{\circ} \mathrm{C}$, respectively. The ionization method was electron impact at a voltage of $70 \mathrm{eV}$. The spectra were obtained over a mass range of $m / z$ 41-650. The data were processed by the Shimadzu GCMS Postrun software. For identification, mass spectra were compared with the NIST library (NIST17-1, NIST17-2, NIST17s) to identify related molecules. The fragmentation patterns and retention indices published in the literature were used to suggest candidate molecules. The proposed molecules were purchased, and GC-MS analyzed using the same instrumental method. The identity of a compound was confirmed by comparing retention time and fragmentations of the authentic molecule. The used solvents, including absolute ethanol, hexane, ethyl acetate, and dichloromethane (DCM) were routinely subjected to GC-MS runs to effectively identify and eliminate impurities.

\subsection{Quantification of Known Bactrocera Attractants in P. maliformis}

The amounts of raspberry ketone, cuelure, zingerone, and zingerol in the collected flower parts were estimated by reference to standard curves. Stock solutions of raspberry ketone, cuelure, zingerone, and zingerol were prepared in volumetric flasks $(5 \mathrm{~mL})$, and a series of standard solutions were prepared by serial dilution of the stock solutions. An aliquot of $1.0 \mu \mathrm{L}$ internal standard solution (tridecane, $1.06 \mathrm{mg} / \mathrm{mL}$ ) was added to the standards and samples to give a final concentration of $5.30 \mu \mathrm{g} / \mathrm{mL}$. The standard and sample solutions were run through GC-MS, and the peak area ratios of the analytes to the internal standard were plotted against ratios of known concentrations of the analytes to the internal standard to obtain standard curves. The concentration of a sample was estimated using the slope of the standard curve, and the amounts of these compounds were subsequently estimated using the original volume of a sample for each flower part.

\subsection{Chromatographic Purification of Unknown Compounds}

Following the analyses of the flower parts, all of the corona sample solutions were pooled, and the solvent was evaporated under reduced pressure. The residue was separated by double flash column chromatography with ethyl acetate/hexane (0-20\% ethyl acetate in hexane $(v / v)$, gradient) as a solvent system to give 3-ethyl-2,3-dihydro-4H-pyran-4-one and 1-(4-methyl-1,3-dioxolan-2-yl)pentan-3-one, where the chromatographic fractions were monitored by GC. The NMR spectra of the compounds were obtained to support the identities of the compounds. 


\subsection{Data Analysis}

The data were not normally distributed, and hence were log transformed for statistical analysis. However, the raw data were used to generate graphs. The change in the amounts of the compounds present in the flower tissues through the day were analyzed by a linear model to see whether the amount of a compound changes with flower collection time. In the analysis, collection time was the independent variable, the detected mass of compound was the dependent variable. Some of the amounts of the compounds were significantly different throughout the day. To compare the amount of a compound between collection times, normally, a posthoc analysis can be followed. Instead, we were interested in decay patterns, and hence further analyzed by a non-linear curve fitting method with the Function (1).

$$
f(y)=A \times e^{-k \times x}+\varepsilon,
$$

where, $\mathrm{A}=$ Initial value for $\mathrm{x}, \mathrm{k}=$ slope, and $\varepsilon=$ correction factor. Data were analyzed using $\mathrm{R}$ (v3.6.1., R Core Team, 2019).

Supplementary Materials: The following are available online, Figure S1. Mass spectrum and diagnostic ions of 3-ethyl-2,3-dihydro- 4H-pyran-4-one; Figure S2. Mass spectrum and diagnostic ions of 1-(4-methyl1,3-dioxolan-2-yl)pentan-3-one, Figure S3. Residual plots of raspberry ketone in the inner coronal filament, zingerone in both filaments, and cuelure in the outer coronal filament from exponential decay fitting, Figure S4. Flower of P. maliformis and B. jarvisi males visiting.

Author Contributions: Conceptualization, P.W.T., S.G.D.F. and S.J.P.; methodology, S.J.P., S.G.D.F. and J.C.; formal analysis, S.J.P.; investigation, S.J.P., J.C., B.L.H. and D.N.S.C.; resources, I.M.J. and P.W.T.; writing-original draft preparation, S.J.P.; writing—review and editing, P.W.T., S.G.D.F., I.M.J., B.L.H. and D.N.S.C.; supervision, P.W.T.; funding acquisition, P.W.T. All authors have read and agreed to the published version of the manuscript.

Funding: This research was supported by funds from the Australian Research Council Industrial Transformation Training Centre for Fruit Fly Biosecurity Innovation (Project IC150100026), including a Research Fellowship for S.J.P. This research was co-supported by the Queensland Department of Agriculture and Fisheries (QDAF).

Acknowledgments: The authors gratefully acknowledge Nazma Akter Tithi for helping the preparation of samples.

Conflicts of Interest: The authors declare no conflict of interest.

\section{References}

1. Metcalf, R.L.; Metcalf, E.R. Plant Kairomones in Insect Ecology and Control; Champmon and Hall: New York, NY, USA, 1992.

2. Tan, K.H.; Nishida, R. Zingerone in the floral synomone of Bulbophyllum baileyi (Orchidaceae) attracts Bactrocera fruit flies during pollination. Biochem. Syst. Ecol. 2007, 35, 334-341. [CrossRef]

3. Tan, K.H.; Tan, L.T.; Nishida, R. Floral phenylpropanoid cocktail and architecture of Bulbophyllum vinaceum orchid in attracting fruit flies for pollination. J. Chem. Ecol. 2006, 32, 2429-2441. [CrossRef] [PubMed]

4. Tan, K.H.; Nishida, R. Synomone or kairomone?-Bulbophyllum apertum flower releases raspberry ketone to attract Bactrocera fruit flies. J. Chem. Ecol. 2005, 31, 497-507.

5. Nishida, R.; Tan, K.-H.; Wee, S.-L.; Hee, A.K.-W.; Toong, Y.-C. Phenylpropanoids in the fragrance of the fruit fly orchid, Bulbophyllum cheiri, and their relationship to the pollinator, Bactrocera papayae. Biochem. Syst. Ecol. 2004, 32, 245-252. [CrossRef]

6. Tan, K.H.; Nishida, R.; Toong, Y.C. Floral synomone of a wild orchid, Bulbophyllum cheiri, lures Bactrocera fruit flies for pollination. J. Chem. Ecol. 2002, 28, 1161-1172. [CrossRef] [PubMed]

7. Tan, K.H. Fruit fly pests as pollinators of wild orchids. In Proceedings of the 7th International Symposium on Fruit Flies of Economic Importance, Salvador, Brazil, 10-15 September 2006.

8. Tan, K.H. Fruit flies (Bactrocera spp.) as pests and pollinators. Sab. Soc. J. 2000, 17, 37-56.

9. Tan, K.H.; Nishida, R. Pollination of bactrocerophilous Bulbophyllum orchids. In Proceedings of the 20th World Orchid Conference, Singapore, 13-20 November 2011.

10. Park, S.J.; Morelli, R.; Hanssen, B.L.; Jamie, J.F.; Jamie, I.M.; Siderhurst, M.S.; Taylor, P.W. Raspberry ketone analogs: Vapour pressure measurements and attractiveness to Queensland fruit fly, Bactrocera tryoni (Froggatt) (Diptera: Tephritidae). PLoS ONE 2016, 11. [CrossRef] 
11. Park, S.J.; Siderhurst, M.S.; Jamie, I.; Taylor, P.W. Hydrolysis of Queensland fruit fly, Bactrocera tryoni (Froggatt), attractants: Kinetics and implications for biological activity. Aust. J. Chem. 2016, 69, 1162-1166. [CrossRef]

12. Tan, K.H.; Nishida, R. Mutual reproductive benefits between a wild orchid, Bulbophyllum patens, and Bactrocera fruit flies via a floral synomone. J. Chem. Ecol. 2000, 26, 533-546. [CrossRef]

13. Shelly, T.E.; Dewire, A.-L.M. Chemically mediated mating success in male oriental fruit flies (Diptera: Tephritidae). Ann. Entomol. Soc. Am. 1994, 87, 375-382. [CrossRef]

14. Wee, S.-L.; Tan, K.H.; Nishida, R. Pharmacophagy of methyl eugenol by males enhances sexual selection of Bactrocera carambolae. J. Chem. Ecol. 2007, 33, 1272-1282. [CrossRef] [PubMed]

15. Kumaran, N.; Balagawi, S.; Schutze, M.K.; Clarke, A.R. Evolution of lure response in tephritid fruit flies: Phytochemicals as drivers of sexual selection. Anim. Behav. 2013, 85, 781-789. [CrossRef]

16. Kumaran, N.; Clarke, A.R. Indirect effects of phytochemicals on offspring performance of Queensland fruit fly, Bactrocera tryoni (Diptera: Tephritidae). J. Appl. Entomol. 2014, 138, 361-367. [CrossRef]

17. Kumaran, N.; Hayes, R.A.; Clarke, A.R. Cuelure but not zingerone make the sex pheromone of male Bactrocera tryoni (Tephritidae: Diptera) more attractive to females. J. Insect Physiol. 2014, 68, 36-43. [CrossRef] [PubMed]

18. Hancock, D.L.; Hamacek, E.L.; Lloyd, A.C.; Elson-Harris, M.M. The Distribution and Host Plants of Fruit Flies (Diptera: Tephritidae) in Australia; Information Series (Queensland Department of Primary Industries); DPI Publications: Brisbane, Australia, 2000.

19. Fitt, G.P. The influence of a shortage of hosts on the specificity of oviposition behaviour in species of Dacus (Diptera, Tephritidae). Physiol. Entomol. 1986, 11, 133-143. [CrossRef]

20. Drew, R.A.I. The tropical fruit flies (Diptera: Tephritidae: Dacinae) of the Australian and Oceanian regions. Mem. Queensl. Mus. 1989, 26, 521.

21. Wee, S.-L.; Peek, T.; Clarke, A.R. The responsiveness of Bactrocera jarvisi (Diptera: Tephritidae) to two naturally occurring phenylbutaonids, zingerone and raspberry ketone. J. Insect Physiol. 2018, 109, 41-46. [CrossRef]

22. Fay, H.A.C. A highly effective and selective male lure for Bactrocera jarvisi (Tryon) (Diptera: Tephritidae). Aust. J. Entomol. 2012, 51, 189-197. [CrossRef]

23. May, A.W.S. Queensland host records for the Dacinae (fam. Try-petidae). Qld. J. Agric. Sci. 1953, 17, $195-200$.

24. Halevy, A.H. Handbook of Flowering; Taylor \& Francis: Boca Raton, FL, USA, 1989.

25. Nyanzi, S.A.; Carstensen, B.; Schwack, W. A comparative study of fatty acid profiles of Passiflora seed oils from Uganda. J. Am. Oil Chem. Soc. 2005, 82, 41-44. [CrossRef]

26. Shiamala, D.R.; Sidik, B.J.; Harah, Z.M.; Sing, K.W.; Arif, S.S.M. Sugars, ascorbic acid, total phenolic content and total antioxidant activity in passion fruit (Passiflora) cultivars. J. Sci. Food Agric. 2013, 93, 1198-1205.

27. Willis, J.M.G. Passion fruits and granadillas. Qld. Agric. J. 1954, 79, 205-217.

28. Restrepo, P.; Duque, C. Componentes volatiles de la gulupa Passiflora maliformis. Rev. Colomb. Quim. 1988, 17, 57-63.

29. Brieze-Stegeman, R.; Rice, M.J.; Hooper, G.H.S. Daily periodicity in attraction of male tephritid fruit flies to synthetic chemical lures. Aust. J. Entomol. 1978, 17, 341-346. [CrossRef]

30. Weldon, C.W.; Perez-Staples, D.; Taylor, P.W. Feeding on yeast hydrolysate enhances attraction to cue-lure in Queensland fruit flies, Bactrocera tryoni. Entomol. Exp. Appl. 2008, 129, 200-209. [CrossRef]

31. Manoukis, N.C.; Jang, E.B. The diurnal rhythmicity of Bactrocera cucurbitae (Diptera: Tephritidae) attraction to cuelure: Insights from an interruptable lure and computer vision. Ann. Entomol. Soc. Am. 2013, 106, 136-142. [CrossRef]

32. Hazzit, M.; Baaliouamer, A.; Faleiro, M.L.; Miguel, M.G. Composition of the essential oils of Thymus and Origanum species from Algeria and their antioxidant and antimicrobial activities. J. Agric. Food. Chem. 2006, 54, 6314-6321. [CrossRef]

33. Angioni, A.; Barra, A.; Cereti, E.; Barile, D.; Coïsson, J.D.; Arlorio, M.; Dessi, S.; Coroneo, V.; Cabras, P. Chemical composition, plant genetic differences, antimicrobial and antifungal activity investigation of the essential oil of Rosmarinus officinalis L. J. Agric. Food. Chem. 2004, 52, 3530-3535. [CrossRef]

34. Mebazaa, R.; Mahmoudi, A.; Fouchet, M.; Santos, M.D.; Kamissoko, F.; Nafti, A.; Cheikh, R.B.; Rega, B.; Camel, V. Characterisation of volatile compounds in Tunisian fenugreek seeds. Food Chem. 2009, 115, 1326-1336. [CrossRef] 
35. Kotowska, U.; Żalikowski, M.; Isidorov, V.A. HS-SPME/GC-MS analysis of volatile and semi-volatile organic compounds emitted from municipal sewage sludge. Environ. Monit. Assess. 2012, 184, 2893-2907. [CrossRef]

36. Zhou, Q.; Wintersteen, C.L.; Cadwallader, K.R. Identification and quantification of aroma-active components that contribute to the distinct malty flavor of buckwheat honey. J. Agric. Food. Chem. 2002, 50, 2016-2021. [CrossRef] [PubMed]

37. Pino, J.A.; Mesa, J.; Muñoz, Y.; Martí, M.P.; Marbot, R. Volatile components from mango (Mangifera indica L.) cultivars. J. Agric. Food. Chem. 2005, 53, 2213-2223. [CrossRef] [PubMed]

38. Dob, T.; Dahmane, D.; Chelghoum, C. Essential oil composition of Juniperus oxycedrus growing in Algeria. Pharm. Biol. 2006, 44, 1-6. [CrossRef]

39. Boussaada, O.; Ammar, S.; Saidana, D.; Chriaa, J.; Chraif, I.; Daami, M.; Helal, A.N.; Mighri, Z. Chemical composition and antimicrobial activity of volatile components from capitula and aerial parts of Rhaponticum acaule DC growing wild in Tunisia. Microbiol. Res. 2008, 163, 87-95. [CrossRef] [PubMed]

40. Roussis, V.; Tsoukatou, M.; Petrakis, P.V.; Ioanna, C.; Skoula, M.; Harborne, J.B. Volatile constituents of four Helichrysum species growing in Greece. Biochem. Syst. Ecol. 2000, 28, 163-175. [CrossRef]

41. Radulović, N.; Blagojević, P.; Palić, R. Comparative study of the leaf volatiles of Arctostaphylos uva-ursi (L.) Spreng.; Vaccinium vitis-idaea L. (Ericaceae). Molecules 2010, 15, 6168-6185.

42. Ferhat, M.A.; Tigrine-Kordjani, N.; Chemat, S.; Meklati, B.Y.; Chemat, F. Rapid extraction of volatile compounds using a new simultaneous microwave distillation: Solvent extraction device. Chromatographia 2007, 65, 217-222. [CrossRef]

43. Zhao, Y.; Li, J.; Xu, Y.; Duan, H.; Fan, W.; Zhao, G. Extraction, preparation and identification of volatile compounds in Changyu XO brandy. Chin. J. Chrom. 2008, 26, 212-222. [CrossRef]

44. Zhao, C.-X.; Li, X.-N.; Liang, Y.-Z.; Fang, H.-Z.; Huang, L.-F.; Guo, F.-Q. Comparative analysis of chemical components of essential oils from different samples of Rhododendron with the help of chemometrics methods. Chemometrics Intellig. Lab. Syst. 2006, 82, 218-228. [CrossRef]

45. Benkaci-Ali, F.; Baaliouamer, A.; Meklati, B.Y.; Chemat, F. Chemical composition of seed essential oils from Algerian Nigella sativa extracted by microwave and hydrodistillation. Flavour. Fragr. J. 2007, 22, 148-153. [CrossRef]

46. Povolo, M.; Pelizzola, V.; Ravera, D.; Contarini, G. Significance of the nonvolatile minor compounds of the neutral lipid fraction as markers of the origin of dairy products. J. Agric. Food. Chem. 2009, 57, 7387-7394. [CrossRef]

47. Grünler, J.; Ericsson, J.; Dallner, G. Branch-point reactions in the biosynthesis of cholesterol, dolichol, ubiquinone and prenylated proteins. Biochim. Biophys. Acta 1994, 1212, 259-277. [CrossRef]

48. Begley, T.P.; Keeling, C.I.; Bohlmann, J. Plant Terpenoids. In Wiley Encyclopedia of Chemical Biology; Begley, T.P., Ed.; John Wiley \& Sons, Inc.: Hoboken, NJ, USA, 2008; pp. 1-10.

49. Lincoln, D.E.; Lawrence, B.M. The volatile constituents of camphorweed, Heterotheca subaxillaris. Phytochemistry 1984, 23, 933-934. [CrossRef]

50. Wong, K.C.; Ong, K.S.; Lim, C.L. Compositon of the essential oil of rhizomes of Kaempferia galanga L. Flavour. Fragr. J. 1992, 7, 263-266. [CrossRef]

51. Jafari, E.; Ghanbarian, G.; Bahmanzadegan, A. Essential oil composition of aerial parts of Micromeria persica Boiss from Western of Shiraz, Iran. Nat. Prod. Res. 2018, 32, 991-996. [CrossRef] [PubMed]

52. Ho, T.I.; Cheng, M.C.; Peng, S.M. Structure of terpin. Aeta Cryst. 1986, 42, 1787-1789. [CrossRef]

53. Loreto, F.; Dicke, M.; Schnitzler, J.-P.; Turlings, T.C.J. Plant volatiles and the environment. Plant. Cell Environ. 2014, 37, 1905-1908. [CrossRef]

54. Tholl, D. Biosynthesis and biological functions of terpenoids in plants. In Biotechnology of Isoprenoids; Schrader, J., Bohlmann, J., Eds.; Springer International Publishing: Cham, Switzerland, 2015; pp. 63-106.

55. Dicke, M.; Baldwin, I.T. The evolutionary context for herbivore-induced plant volatiles: Beyond the 'cry for help'. Trends Plant. Sci. 2010, 15, 167-175. [CrossRef]

56. Gershenzon, J. Metabolic costs of terpenoid accumulation in higher plants. J. Chem. Ecol. 1994, 20, 1281-1328. [CrossRef]

57. Pichersky, E.; Raguso, R.A.; Lewinsohn, E.; Croteau, R. Floral scent production in Clarkia (Onagraceae) (I. Localization and developmental modulation of monoterpene emission and linalool synthase activity). Plant. Physiol. 1994, 106, 1533-1540. [CrossRef] 
58. Heidi, E.M.D.; Groth, I.; Bergstrom, G. Pollen advertisement: Chemical contrasts between whole-flower and pollen odors. Am. J. Bot. 1996, 83, 877-885.

59. Evans, K.A.; Allen-Williams, L.J. Electroantennogram responses of the cabbage seed weevil, Ceutorhynchus assimilis, to oilseed rape, Brassica napus ssp. oleifera, volatiles. J. Chem. Ecol. 1992, 18, 1641-1659. [CrossRef] [PubMed]

60. Robertson, G.W.; Griffiths, D.W.; Smith, W.M.; Butcher, R.D. The application of thermal desorption-gas chromatography-mass spectrometry to the analyses of flower volatiles from five varieties of oilseed rape (Brassica napus spp. oleifera). Phytochem. Anal. 1993, 4, 152-157. [CrossRef]

61. Baldwin, I.T. Plant volatiles. Curr. Biol. 2010, 20, 392-397. [CrossRef]

62. Raffaele, S.; Leger, A.; Roby, D. Very long chain fatty acid and lipid signaling in the response of plants to pathogens. Plant. Signal. Behav. 2009, 4, 94-99. [CrossRef]

63. Vogt, T. Phenylpropanoid biosynthesis. Mol. Plant. 2010, 3, 2-20. [CrossRef]

64. Dudareva, N.; Pichersky, E.; Gershenzon, J. Biochemistry of plant volatiles. Plant. Physiol. 2004, 135, 1893-1902. [CrossRef]

65. Horiuchi, J.; Badri, D.V.; Kimball, B.A.; Negre, F.; Dudareva, N.; Paschke, M.W.; Vivanco, J.M. The floral volatile, methyl benzoate, from snapdragon (Antirrhinum majus) triggers phytotoxic effects in Arabidopsis thaliana. Planta 2007, 226, 1-10. [CrossRef]

66. Lu, S.; Xu, R.; Jia, J.-W.; Pang, J.; Matsuda, S.P.T.; Chen, X.-Y. Cloning and functional characterization of a $\beta$-pinene synthase from Artemisia annua that shows a circadian pattern of expression. Plant. Physiol. 2002, 130, 477-486. [CrossRef]

67. Helsper, J.P.F.G.; Davies, J.A.; Bouwmeester, H.J.; Krol, A.F.; van Kampen, M.H. Circadian rhythmicity in emission of volatile compounds by flowers of Rosa hybrida L. cv. Honesty. Planta 1998, 207, 88-95. [CrossRef]

68. Jakobsen, H.B.; Olsen, C.E. Influence of climatic factors on emission of flower volatiles in situ. Planta 1994, 192, 365-371. [CrossRef]

69. Zhang, L.; Wang, H. Analysis of volatile components in mulberry fruit sparkling wine by gas chromatography/mass spectrometry. Canye Kexue 2010, 36, 152-156.

70. Nishida, R.; Tan, K. Search for new fruit fly attractants from plants: A review. In Proceedings of the 9th International Symposium on Fruit Flies of Economic Importance, Bangkok, Thailand, 12-16 May 2014.

71. Katte, T.; Tan, K.H.; Su, Z.-H.; Ono, H.; Nishida, R. Floral fragrances in two closely related fruit fly orchids, Bulbophyllum hortorum and B. macranthoides (Orchidaceae): Assortments of phenylbutanoids to attract tephritid fruit fly males. Appl. Entomol. Zool. 2020, 55, 55-64. [CrossRef]

72. Christenson, L.D.; Foote, R.H. Biology of fruit flies. Annu. Rev. Entomol. 1960, 5, 171-192. [CrossRef]

73. Tan, K.H.; Nishida, R.; Jang, E.B.; Shelly, T.E. Pheromones, male lures, and trapping of tephritid fruit flies. In Trapping and the Detection, Control, and Regulation of Tephritid Fruit Flies: Lures, Area-Wide Programs, and Trade Implications; Tan, K.H., Nishida, R., Jang, E.B., Shelly, T.E., Eds.; Springer: Dordrecht, The Netherlands, 2014; pp. 15-74.

74. Shivanna, K.R. Reproductive assurance through unusual autogamy in the absence of pollinators in Passiflora edulis (passion fruit). Curr. Sci. 2012, 103, 1091-1096.

75. Yamamoto, M.; da Silva, C.I.; Augusto, S.C.; Barbosa, A.A.A.; Oliveira, P.E. The role of bee diversity in pollination and fruit set of yellow passion fruit (Passiflora edulis forma flavicarpa, Passifloraceae) crop in central Brazil. Apidologie 2012, 43, 515-526. [CrossRef]

76. Janzen, D.H. Reproductive behavior in the Passifloraceae and some of its pollinators in Central America. Behaviour 1968, 32, 33-48. [CrossRef]

77. Sazima, M.; Sazima, I. Bat pollination of the passion flower, Passiflora mucronata, in Southeastern Brazil. Biotropica 1978, 10, 100-109. [CrossRef]

78. Varela, G.; Cocucci, A.; Sersic, A.N. Role of the corona in Passiflora caerulea (Passifloraceae) as attractant to their pollinators. Boletin de la Sociedad Argentina de Botanica 2016, 51, 99-110. [CrossRef]

(C) 2020 by the authors. Licensee MDPI, Basel, Switzerland. This article is an open access article distributed under the terms and conditions of the Creative Commons Attribution (CC BY) license (http://creativecommons.org/licenses/by/4.0/). 